\section{Sealing Ability of MTA Used as a Root End Filling Material: Effect of the Sonic and Ultrasonic Condensation}

Pedro Felício Estrada Bernabé, João Eduardo Gomes-Filho, Daniel Galera Bernabé, Mauro Juvenal Nery, José Arlindo Otoboni-Filho, Eloi Dezan-Jr, Luciano Tavares Angelo Cintra
Department of Restorative Dentistry, Araçatuba Dental School, UNESP - Univ Estadual Paulista, Araçatuba, SP, Brazil

Correspondence: Prof. Dr. Luciano Tavares Angelo Cintra, Rua José Bonifácio, 1193, Vila Mendonça, 16015-050 Araçatuba, SP, Brasil. Tel: +55-18-3636-2867. e-mail: lucianocintra@foa.unesp.br

\begin{abstract}
Despite the excellent properties of mineral trioxide aggregate (MTA), the condensation technique may have some influence in its sealing ability. The purpose of this study was to compare the sealing ability of sonic and ultrasonic setting of MTA. Thirty-four extracted human teeth had their canals prepared and filled with Sealapex sealer and gutta-percha using the active lateral condensation technique. The teeth were rendered waterproof and apicoectomy performed at $3 \mathrm{~mm}$ from the apex. Root-end cavities ( $3.0 \mathrm{~mm}$ deep and 1.4 $\mathrm{mm}$ diameter) were prepared with diamond ultrasonic tips. The root-end cavities were filled with Pro-Root MTA ${ }^{\circledast}$ with ultrasonic vibration, sonic vibration or no vibration. The positive control group did not receive any material while the negative control group was totally rendered waterproof. After material set, the specimens were immersed in Rodhamine B for $24 \mathrm{~h}$, under vacuum in the first $15 \mathrm{~min}$, then washed, dried and split longitudinally for evaluating the infiltration at the dentin/material interface. Data were analyzed using ANOVA and Tukey's tests at 5\% significance level. Sonic vibration promoted the lowest infiltration values $(p<0.05)$. It was concluded that sonic vibration could be considered an efficient aid to improve the sealing ability of MTA when used as root-end filling material.
\end{abstract}

Key Words: sealing ability, apical surgery, root end filing material, MTA, sonic and ultrasonic device.

\section{Introduction}

Despite the high success rate obtained with endodontic treatment, failure may occur and an apical surgery is necessary in these cases. Among the variety of techniques, apicoectomy with retrograde preparation and retrofilling is the most used to achieve the apical sealing.

MTA was originally developed to seal perforations and root-end preparations (1) and it is the most prominent dental material used currently. Its sealing ability has been demonstrated in vitro to be superior to that of amalgam, Super EBA, glass ionomer cement, intermediate restorative material (IRM) and other materials $(1,2)$. MTA has shown adequate biological properties with formation of mineralized tissue in close contact with the material (3), less apical inflammation and deposition of cementum when compared with amalgam, Super EBA, IRM and ZOE in putty like consistency $(4)$. Previous studies $(3,4)$ have demonstrated periapical repair and regeneration of the periodontal ligament when MTA is used in endodontic surgery. It has proven biocompatible both in in vitro and in vivo investigations (3-7).

Despite its favorable characteristics, however, MTA presents less than ideal working properties. The cement resulting from the mixture of powder with liquid is difficult to handle (8), its setting time has been reported to be 2 h $45 \mathrm{~min}$, while its working time is less than $4 \mathrm{~min}$ (8). Additional moisture is also required to activate the setting of the cement (8).
The condensation technique studies are still insufficient to choose the best one intending to improve its sealing ability. Ultrasound activation is employed during crown and post cementation to reduce the cement line and improve the adaptation (9). Sonic vibration is employed during the fabrication of plaster models to reduce the inclusion of air bubbles diminishing its porosity.

Ultrasonic aid has been demonstrated to be positive during MTA condensation $(10,11)$. However, the use of sonic or ultrasonic aid in apical surgery has not been sufficiently explored and clarified. It may be hypothesized that sonic or ultrasonic vibration can improve the condensation and adaptation of MTA in the root-end cavities. Therefore, the aim of this study was to evaluate the sealing ability of MTA root-end-filling material placed using three techniques: 1 . hand condensation with indirect sonic activation; 2 . hand condensation with indirect ultrasonic activation; and 3. hand condensation without indirect activation. The tested hypothesis was that root-end filling with MTA using an optimal amount of sonic and ultrasonic activation would result in a higher fill density, better adaptation and hermetic sealer than compared with hand condensation alone.

\section{Material and Methods}

Thirty-four recently extracted human single-rooted mandibular premolars obtained from the Endodontic Department's tooth bank, were radiographed, examined under magnification for fractures and cracks, and stored 
in $10 \%$ saline for use. All teeth were kept moist before and during the experiment.

The teeth were decoronated using an Endo-Z Bur (Dentsply Maillefer, Tulsa, OK, USA) in a high-speed handpiece with water spray. The root canals were prepared up to a size $40 \mathrm{~K}$-file (Dentsply/Maillefer Instruments, Ballaigues, Switzerland) under abundant irrigation with $1 \% \mathrm{NaOCl}$. EDTA was applied for $3 \mathrm{~min}$, followed by a new irrigation with $1 \% \mathrm{NaOCl}$ and a final irrigation with saline. The root canals were dried with paper points and filled by the active lateral condensation technique with gutta-percha points and Sealapex ${ }^{\circledast}$ (SybronEndo, Glendora, CA, USA). The roots were then rendered waterproof with nail polish, except for the apex, and apicoectomy was performed at $3.0 \mathrm{~mm}$ from the apex with a Zeckrya drill (Dentsply/Maillefer Instruments). Root-end cavities $(3.0 \mathrm{~mm}$ deep and $1.4 \mathrm{~mm}$ diameter) were prepared with ultrasonic diamond tips (Fig. 1), irrigated with saline and dried with paper points. All procedures were performed by the same operator. The teeth were randomly assigned to 5 groups. The positive control group ( 2 teeth) did not receive any material while the teeth in the negative control group (2 teeth) were completely waterproofed, including the apex. MTA was handled according to manufacturer's instruction and randomly inserted into the root-end cavities according to the technique of insertion of each group with similar working time. In one experimental group $(n=10)$, MTA was inserted with the \#5 condenser $(0.6 \mathrm{~mm}$ diameter $\times 3.0 \mathrm{~mm}$ long) of the set of instruments developed for apical surgery (Sansers Ltda, São Paulo, SP, Brazil). Portions of material were inserted into the cavity and the ultrasonic diamond
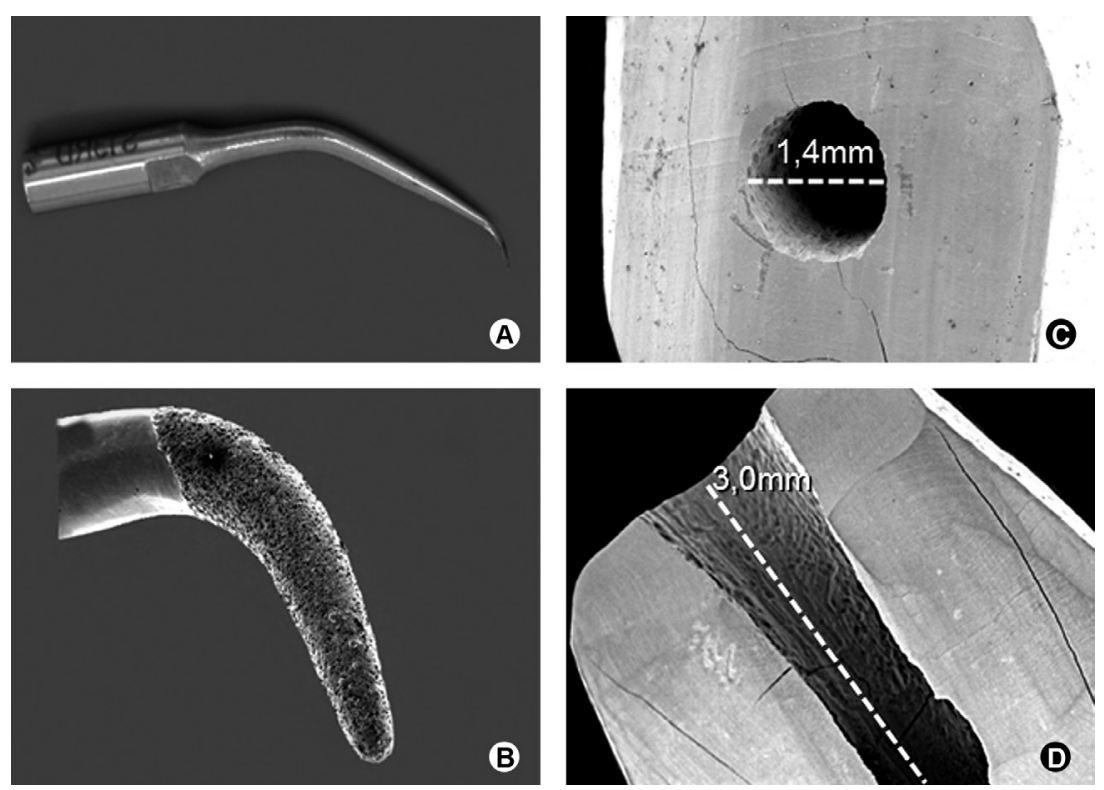

Figure 1. A: Diamond tip. B: SEM micrograph of the P15 diamond tip. C: SEM micrograph of a tooth with apicoectomy and root-end cavity. D: SEM micrograph of a split root-end cavity. tip (P15-LD; Gnatus, Ribeirão Preto, SP, Brazil) was placed in contact with the condenser (indirectly activated) for 1 s. This filling procedure was repeated four more times in order to completely fill the cavity. The ultrasonic device was set under minimal power, according to Kim et al. (12). In the other experimental group $(n=10)$, the same procedures were performed, except for the use of sonic vibration. In these cavities, a sonic vibrator device provided with two 1.5 V batteries (Pau Brazil, São Paulo, SP, Brazil) was used instead. In the last experimental group $(n=10)$, MTA was inserted with the condenser in cavities in portions and condensed manually with neither sonic nor ultrasonic devices. This filling procedure was repeated four times in order to fill the cavity completely in a similar manner to Groups 1 and 2, except the vibration.

After completing the retrofillings, the roots were kept in oven and in humid atmosphere for $24 \mathrm{~h}$, when the specimens were immersed in $\mathrm{pH}$ 7.0 Rhodamine $B$ (Labsynth Produtos para Laboratórios Ltda, Araçatuba, SP, Brazil) for $24 \mathrm{~h}$, under vacuum $(0.002 \mathrm{mmHg})$ during the first $15 \mathrm{~min}$. The surfaces of the teeth were grooved longitudinally with a cylindrical diamond tip and split with the aid of a chisel and a little hammer.

The infiltrations were evaluated in a blind manner by a single calibrated examiner, considering the deepest linear measurement of each specimen obtained in the area of leakage between the material and the dentin surface.

The images were captured with a video camera coupled to an optical microscope and the measures were made using SigmaScan ${ }^{\oplus}$ software (Systat Software Inc., Richmond, CA, USA). Statistical analysis was made using ANOVA and Tukey's test at a significance level of 5\% (Fig. 2).

\section{Results}

The analysis of the levels of infiltration showed total infiltration of the tracer element in all samples of the positive control group and no infiltration was observed in the specimens of the negative control group. The experimental groups presented different infiltration levels.

In all specimens, indirect sonic activation of MTA resulted in a better sealing ability compared with hand condensation alone or ultrasonic activation. Classification of the groups from best to the worst, according to the interfacial sealing against trace infiltration was as follows: sonic vibration $(0.89 \pm 0.07$ 
$\mathrm{mm})$, ultrasonic vibration $(1.08 \pm 0.09 \mathrm{~mm})$ and no vibration $(1.12 \pm 0.09 \mathrm{~mm})$. Only the group with sonic vibration was statistically different from the others $(p<0.05)$.

\section{Discussion}

When the endodontic treatment fails, a surgical complementation by apicoectomy and a root-end preparation and filling may be necessary to promote the hermetic sealing of the root canal system.

In this way, the sealing ability of the root-end filling materials is important to achieve success. Biological properties of the root-end filling materials are quite important, however, it is also certain that the prevention of the irritant infiltration to the periapical tissues contributes to the occurrence of the healing process justifying the importance of studies related to the material's sealing ability.

MTA was chosen for the present study due to its favorable physical and biological properties, which favor its wide use (1-8). It has been demonstrated that MTA has the smallest infiltration rate compared with the other retrofilling materials (8).

There is a lot of skepticism about the relevance of in vitro leakage studies as regards the significance and limitations of the results (13). Even so, they are widely used to evaluate and compare the sealing efficiency of materials, as well as other porperties, prior to the use in patients. Although in the present experiment the intensity of coloration produced after the infiltration was not evaluated, Rhodamine B was used because it does not suffer discoloration by calcium oxide materials as it occurs with methylene blue (2). Vacuum was used based on studies that showed higher levels of infiltration when it was employed compared with groups without it, probably due to the presence of voids in the mass of the obturation that difficult the dye penetration but not the bacteria $(2,12)$.

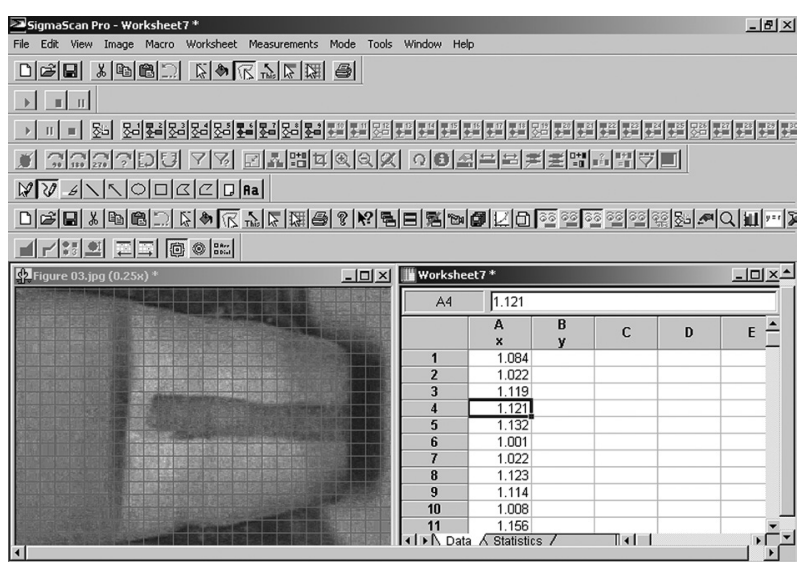

Figure 2. Measurement of trace infiltration by the software SigmaScan ${ }^{\circledR}$.
Despite the MTA properties, the condensation technique may have some influence on its sealing ability $(10,11)$. In the literature, it is possible to notice lack of papers related to its insertion or condensation. Surgical amalgam carrier or Centrix ${ }^{\oplus}$ device can be used, but due to the anatomy of the site, their application is difficult (14). A rectangular resin block with several perforations containing small portions of MTA can be used to carry the material into the cavity if a wet gaze is placed over the material to avoid dehydration (14). Another method of insertion uses specific devices such as that proposed by Messin Gun (15). Anyway, the ideal technique was not yet established to insert and condense the MTA into the root-end cavities.

Vibration is used in Dentistry to diminish the voids in the material, making it uniform and dense. It was shown that the utilization of vibration during cementation of crowns and posts diminished the line of cement and improved the adaptation $(9,16)$. Other studies reported that ultrasonic activation improved the mechanical properties of glass ionomer cement due to the wider contact between the glass ionomer particles and the poliacid, resulting on a larger reactive surface of glass and on the improvement of material density (17-19). Vibration has been used during the ortograde root canal filling leading to a low apical infiltration rate (20-22).

Ultrasonic vibration improved the sealing ability of MTA in the present study. Similar results were obtained using different methodologies, in previous reports (1012). Yeung et al. (11) compared the fill density of MTA produced by hand condensation with that produced by hand condensation with indirect ultrasound activation. According to the authors, hand condensation with indirect ultrasonic activation resulted in an MTA fill that was significantly heavier, and thus denser, than the one accomplished by hand condensation alone, both in curved and straight canals. Kim et al. (12) investigated the density of MTA apical plug condensed either by hand or ultrasound and reported that adjunct use of ultrasound produced denser MTA apical plugs. According to Lawley et al. (10), the ultrasonically placed MTA followed by composite provided a significantly better MTA seal than without ultrasound.

The mean of infiltration observed in the group without mechanical activation agrees with previous reports that found an effective sealing with the use of MTA $(1,8)$. The group where MTA was condensed with ultrasound aid showed lower rate of infiltration than the control group but without statistical significance. It is important to report that ultrasound sometimes displaced the material out of the cavity, compromising the condensation. It was necessary to regulate the power of the device to the lowest (Power 1). The need of a lower power is reinforced by the values found in the group of the condensation with 
sonic vibration, where an improvement in the quality of sealing was observed. In this group, the sonic vibration was obtained by a battery power vibrator, which provided a lower intensity vibration, allowing a better adaptation of the root-end filling material at the same time that it was condensed. Although the results with sonic vibration were better than those of ultrasound, this difference should be further evaluated in future works.

Considering the limitations of this study, it was found that the degree of condensation of MTA retrofilling material could be affected by the use of ultrasonic activation. From these results it may be inferred that sonic vibration or ultrasound during the condensation of the root-end filling material can improve the quality of the sealing.

Comparing the results, this study provides a first study in literature with sonic vibration as an aid to endodontic surgical procedures. Further studies on the mode and application time of sonic or ultrasound activation to increase the sealing ability of MTA apical plug are required. In addition, devices, power and vibration width are factors that should be considered and better evaluated.

It was possible to conclude using the methodology and conditions of the present study, that the use of sonic vibration provided a significantly lower infiltration rate than the use of ultrasound or no vibration.

\section{Resumo}

0 objetivo deste estudo foi avaliar in vitro, a influência da vibração sônica e ultrassônica no selamento marginal proporcionado pelo MTA. Trinta e quatro dentes humanos tiveram seus canais radiculares instrumentados e obturados com cimento Sealape ${ }^{\circledR}$ pela técnica da condensação lateral ativa. Os dentes foram impermeabilizados e seccionados os $3 \mathrm{~mm}$ apicais. Retrocavidades ( $3 \mathrm{~mm}$ de profundidade e 1,4 $\mathrm{mm}$ de diâmetro) foram preparadas com pontas ultrassônicas diamantadas. As retrocavidades foram preenchidas com Pro-Root MTA ${ }^{\oplus}$ com auxilio da vibração ultrassônica, com auxilio da vibração sônica e sem vibração alguma. 0 grupo controle positivo não recebeu material retrobturador, enquanto que o negativo foi totalmente impermeabilizado. Após a presa do material, os espécimes foram mergulhados em Rodamina B por 15 min em vácuo, permanecendo nesta solução por mais $24 \mathrm{~h}$. Em seguida, foram lavados, secados e clivados longitudinalmente para avaliação da infiltração do corante na interface dentina/material retrobturador. Os dados foram analisados utilizando a análise de variância e o teste de Tukey $(p<0,05)$. Observou-se que apenas a vibração sônica foi diferente apresentando os menores indices de infiltração. Pode-se concluir que vibração sônica contribui com a melhora da capacidade de selamento marginal proporcionado pelo MTA quando empregado como material retrobturador.

\section{References}

1. Torabinejad M, Watson TF, Pitt Ford T. Sealing ability of a mineral trioxide aggregate when used as a root end filling material. J Endod 1993;19:591-595.

2. Orosco FA, Bramante CM, Garcia RB, Bernardineli N, de Moraes IG. Sealing ability, marginal adaptation and their correlation using three root-end filling materials as apical plugs. J Appl Oral Sci 2010;18:127134.
3. Bernabé PF, Gomes-Filho JE, Rocha WC, Nery MJ, Otoboni-Filho JA, Dezan-Júnior E. Histological evaluation of MTA as a root-end filling material. Int Endod J 2007;40:758-765.

4. Bernabé PF, Holland R, Morandi R, de Souza V, Nery MJ, Otoboni Filho JA, et al.. Comparative study of MTA and other materials in retrofilling of pulpless dogs' teeth. Braz Dent J 2005;16:149-155.

5. Cintra LTA, Moraes IG, Bernabé PFE, Gomes-Filho JE, Bramante CM, Garcia RB, et al.. Evaluation of the tissue response to MTA and MBPC: Microscopic analysis of implants in alveolar bone of rats. J Endod 2006;32:556-559.

6. Cunha SA, Rached FJ Jr, Alfredo E, León JE, Perez DE. Biocompatibility of sealers used in apical surgery: a histological study in rat subcutaneous tissue. Braz Dent J 2011;22:299-305.

7. Lee BN, Son HJ, Noh HJ, Koh JT, Chang HS, Hwang IN, et al.. Cytotoxicity of newly developed ortho MTA root-end filling materials. J Endod 2012;38:1627-1630.

8. Torabinejad M, Hong CU, MacDonald F, Pitt Ford T. Physical and chemical properties of a new root end filling material. J Endod 1995;21:349-353.

9. Bagis B, Turkaslan S, Vallittu PK, Lassila LV. Effect of high frequency ultrasonic agitation on the bond strength of self-etching adhesives. J Adhes Dent 2009;11:369-374.

10. Lawley GR, Schindler WG, Walker WA 3rd, Kolodrubetz D. Evaluation of ultrasonically placed MTA and fracture resistance with intracanal composite resin in a model of apexification. J Endod 2004;30:167-172.

11. Yeung P, Liewehr FR, Moon PC. A quantitative comparison of the fill density of MTA produced by two placement techniques. J Endod 2006;32:456-459.

12. Kim US, Shin SJ, Chang SW, Yoo HM, Oh TS, Park DS. In vitro evaluation of bacterial leakage resistance of an ultrasonically placed mineral trioxide aggregate orthograde apical plug in teeth with wide open apexes: a preliminary study. Oral Surg Oral Med Oral Pathol Oral Radiol Endod 2009;107:52-56.

13. Wu MK, Wesselink PR. Endodontic leakage studies reconsidered. Part I. Methodology, application and relevance. Int Endod J 1993;26:37-43.

14. Lee ES. A new mineral trioxide aggregate root-end filling technique. J Endod 2000; 26:764-765.

15. Krell KV, Madison S. The use of the Messing gun in placing calcium hydroxide powder. J Endod 1985;11:233-234.

16. Shahid S, Billington RW, Hill RG, Pearson GJ. The effect of ultrasound on the setting reaction of zinc polycarboxylate cements. J Mater Sci Mater Med 2010;21:2901-2905.

17. Gorseta K, Glavina D, Skrinjaric I. Influence of ultrasonic excitation and heat application on the microleakage of glass ionomer cements. Aust Dent J 2012;57:453-457.

18. Moshaverinia A, Ansari S, Moshaverinia M, Schricker SR, Chee WW. Ultrasonically set novel NVC-containing glass-ionomer cements for applications in restorative dentistry. J Mater Sci Mater Med 2011;22:2029-2034.

19. Coldebella CR, Santos-Pinto L, Zuanon AC. Effect of ultrasonic excitation on the porosity of glass ionomer cement: a scanning electron microscope evaluation. Microsc Res Tech 2011;74:54-57.

20. Mazotti D, Sivieri-Araújo G, Berbert FL, Bonetti-Filho I. In vitro evaluation of the obturation ability, adaptation and compaction of gutta-percha in the root canal system employing different filling techniques. Acta Odontol Latinoam 2008;21:3-9.

21. Mente J, Werner S, Koch MJ, Henschel V, Legner M, Staehle HJ, et al.. In vitro leakage associated with three root-filling techniques in large and extremely large root canals. J Endod. 2007;33:306-309.

22. Bailey GC, Ng YL, Cunnington SA, Barber P, Gulabivala K, Setchell DJ. Root canal obturation by ultrasonic condensation of gutta-percha. Part II: an in vitro investigation of the quality of obturation. Int Endod J 2004;37:694-698. 